\title{
Використання спортсменами духовних практик та ритуалів при підготовці до змагань
}

\author{
1Олена Гант \\ ${ }^{2}$ Ксенія Млікова
}

\author{
${ }^{1}$ Харків, Україна \\ ${ }^{2}$ Рига, Латвія
}

\begin{abstract}
Мета: вивчити особливості підготовки до змагань у українських та латишських спортсменів.
Матеріал і методи: аналіз науково-методичної літератури, анкетування, методика «Ціннісні орієнтації» Рокіча. Результати: проведено теоретичний аналіз проблеми психологічної підготовки до змагань у спортсменів. Визначено, що крім класичних психологічних технік спортсмени застосовують різні ритуали та духовці практики. Проаналізовано відношення до відповідальності за результат у змаганнях у латишських та українських спортсменів.

Висновки: 85,72\% обстежених спортсменів, використовують різноманітні ритуальні дії та духовні практики перед змаганнями, та при цьому повністю беруть на себе відповідальність за результат на змаганнях. Використання спортсменам ритуалів та духовних практик, залежить як від культурних особливостей обстежених спортсменів, від їх особистісних орієнтирів та ціннісних орієнтацій, віросповідання та сили нервової системи.
\end{abstract}

Ключові слова: спорт, спортсмени, психологічна підготовка, духовні практики.

\section{Вступ}

Психологічна підготовка спортсменів забезпечую якісний виступ їх на змаганнях. Для досягнення високих змагальних результатів спортсмени та тренери застосовують самі різноманітні методи підготовки [1; 7]. В більшості досліджень в області психології спорту відзначено, що психологічна підготовка - це сукупність психологопедагогічних заходів і відповідних умов спортивної діяльності і життя спортсменів, спрямованих на формування у них таких психічних функцій, процесів, станів і властивостей особистості, які забезпечують успішне вирішення завдань тренування і участі в змаганнях $[2,8]$

В умовах сьогодення термін «психологічна підготовка» все частіше поступається місцем терміну «психологічне забезпечення», який має новий розширений контекст, вказує на більш широкий спектр можливостей роботи спортивного психолога, що передбачає розробку психологічно обґрунтованої організації всього процесу підготовки, а конкретна психологічна підготовка спортсменів до змагань розглядається як частина цієї багатосторонньої роботи [8]

Метою психологічної підготовки спортсменів $є$ подолання та контроль можливих негативних реакцій людини в стресовій ситуації змагальної та тренувальної діяльності. Загальна психологічна підготовка здійснюється в процесі навчання і виховання спортсмена і спрямована на вироблення таких якостей, як мужність, героїзм, хоробрість. В багатьох видах єдиноборств містяться також морально етичні установки і правила поведінки спортсмена $[6,8]$.

Аналіз різноманітної літератури та практика наших досліджень, показують, що навіть найефективніші прийоми психологічного впливу в одному виді діяльності при прямому перенесення в інший нерідко втрачає свою ефективність і не виправдовує покладених на нього сподівань. Різні види спорту є психологічно різними видами діяльності, тому для адекватного вибору засобів для психологічної роботи в конкретному виді спорту слід чітко уявляти собі механізм впливу на психіку спортсмена. Нерідко техніки і методики, розроблені в рамках принципово різних концепцій, призводять до схожих результатів або активують однакові механізми, але буває і навпаки - один і той же, здавалося б, прийом виявляється різноманітним за своїм впливом. Ритуал - це детермінована послідовність дій, регулярне виконання яких призводить до певного психічного стану $[4,7]$.

При цьому різноманітність використовуваних дій і їх тривалість обумовлені тільки метою і умовами застосування, а результатом $є$ зміна психічного стану і міжособистісних взаємин. Зовні ритуал може виглядати і як короткий, практично непомітне дію, наприклад, окремі руху в процесі прийняття бойової стійки в єдиноборствах, і як тривала в часі комплексна процедура з використанням зовнішньої атрибутики і інших людей - дії гравців команди в певні моменти гри: забитий або пропущений гол, таймаут, випадкова пауза в матчі і т.п. [7]

Основними ознаками ритуалу слід вважати що регламентуються дій (аж до уявного промовляння словесних формул), їх обумовленість змагальної ситуацією (в однакові моменти - однакові дії) і цілісну смислову спрямованість: відновити оптимальний баланс емоцій, сконцентрувати увагу на конкретних об'єктах, «відключитися» від зовнішніх перешкод $[7,8]$.

У класифікації методів психорегуляції створення і використання ритуалу слід віднести до наївних або найпростішим методам, в залежності від механізму впливу на психіку. Наприклад, талісмани, «щасливі» місця, номери або сторони, способи шнурівки взуття, послідовність одягання спорядження і тому подібні особливості, які можуть суворо контролюватися спортсменом, несуть в собі елемент віри в надприродні сили, удачу або долю, що є принципово не доказовими і дозволяє назвати ці методи психічного впливу наївними, не дивлячись на їхню соціальну значимість для стану спортсмена $[4,7]$

Найпростішими методами психорегуляції є стандартизовані послідовності дій, які мають психофізіологічний обґрунтування: певний ритм дихання, закривання очей (або погляд «в нікуди») для уявного повторення дії, конкретні рухи та т.д. $[5,7]$

Ритуал в спорті може бути створений для вирішення різних завдань, серед яких найчастіше можна виділити наступні: 


\section{СЛОБОЖАНСЬКИЙ НАУКОВО-СПОРТИВНИЙ ВІСНИК:}

\section{Матеріали XIX Міжнародної науково-практичної конференції «Фізична культура, спорт і здоров'я: стан, проблеми та}

- фрормування адекватного емоційного настрою на виконання змагальної спроби;

- формування конкретної установки на виконання наступного дії, прийому, підходу;

- підготовка функціональних систем організму до майбутнього виконання змагальногодії;

- формування впевненості в успішному завершенні майбутнього дії і всього виступу в цілому;

- закріплення отриманої інфрормації, створення психологічної «опори» в процесі навчання (в психології цього є ще одна назва: психологічний «якір», техніка «якорения»);

- деактуалізація негативних наслідків невдалої спроби, прийому або дії як протилежність попередній задачі з метою відновлення емоційного балансу до оптимального рівня [7]

Таким чином, виконання ритуалу переважно $€$ засобом регуляції психічного стану перед виконанням діяльності. Таку оптимізацію готовності людина проводить практично перед будь-яким запланованим дією, але свідоме ставлення до цього процесу дозволяє істотно підвищити його ефективність. Ритуал може стихійно виникнути в процесі діяльності людини як захисний або регуляційної механізм, і здійснюватися навіть без усвідомлення його виконання, але в більшості випадків має місце свідомо виконувана послідовність дій. В процесі створення і використання ритуалу можна виділити окремі етапи, кожен з яких може стати «ключовим» в роботі з ритуалом і має свої особливості. 3 позиції особливостей практичного використання рекомендують виділяти створення ритуалу його освоєння, усвідомлення обмежень, подолання і усвідомлення подолання обмежень як своєрідний цикл життя ритуалу $[1,7,8]$.

Створення ритуалу - це один з найбільш творчих етапів роботи психолога, коли слід врахувати безліч різних чинників: мета, можливості і умови виконання, індивідуальні особливості спортсмена і т.д. Ритуали створюються освоюються в рамках загальної психологічної підготовки, а конкретизуються і вдосконалюється в період підготовки до певних умов майбутніх змагань, тобто в процесі спеціальної психологічної підготовки $[2,7]$.

Змістритуалу обумовленопсихологічноюпроблемою, яку треба буде розв'язати. Існування проблеми може не усвідомлювати спортсменом і навіть тренером або психологом, але вона може бути виявлена шляхом аналізу змагальної діяльності, психодіагностичних досліджень або емпірично за підсумками виступів. У процесі створення ритуалу важливо виявити справжні причини і розробляти послідовність дій для цілеспрямованої зміни їх негативного впливу на психічний стан $[1,7,8]$

Наприклад, перехід спортсмена від «передстартової лихоманки» в стан «передстартової апатії», тобто емоційне «перегорання» від сильних переживань безпосередньо перед змаганням, яке буває результатом індивідуальних особливостей спортсмена, високу значимість змагань непередбачених зовнішніх умов і інших чинників, може не мати явних зовнішніх проявів і не усвідомлювати са- мим спортсменом. Для кожного з цих випадків потрібен свій ритуал, виконання якого буде можливим за будь-яких умовах i, якщо необхідно, по зовнішній команді тренера або психолога $[2,7]$

\section{Матеріал і методидослідження}

Вивчити особливості підготовки до змагань у україн- ських та латишських спортсменів. Відповідно до поставленої мети вирішуються такі завдання: провести теоретичний аналіз проблеми психологічної підготовки в спорті, а саме використання спортсменами духовних практик та ритуалів перед змаганнями; визначити особливості ціннісних орієнтацій особистості спортсменів; проаналізувати ритуальні дії спортсменів; проаналізовано відношення до відповідальності за результат у змаганнях у латиських та українських спортсменів

Було досліджено спортсменів віком 18-35 років, у кількості 36 осіб, які займаються єдиноборствами. Для обґрунтування актуальності теми проводили теоретикометодологічний аналіз проблеми. Для вивчення особистісної спрямованості спортсменів використовували методику «Ціннісні орієнтації» та анкетування [9]

\section{Результати дослідження}

Першим етапом нашого дослідження став аналіз використання духовних практик та ритуалів у спортсмен в перед змаганнями

За результатами нашого дослідження, 85,72 \% обстежених спортсменів, використовують різноманітні ритуальні дії та духовні практики перед змаганнями, але тільки $77,14 \%$ відсотків респондентів зізналися що то за ритуали.

Аналіз характеру ритуалах дій, які використовують спортсмени перед змаганнями, показав, що 62,96 \% респондентів застосовували різні ритуали з одягом: «щасливі» труси, носки, майка; не прали одяг під час всього етапу змагань та так далі. 25,92 \% спортсменів зверталися за допомогою до «вищих сил», читали молитви та ходили до храмів перед змаганнями. 7,4 \% використовували різні ритуали, які стосувалися їх тіла: не брили бороду та ін.), така ж кількість спортсменів використовували гіпноз. Деякі спортсмени прибігали до використання одразу двох або більше видів ритуальних дій. 37,04 \% використовували навушники та гучно слухали музику, щоб ні на що не відволіктися, за їх словами. Прослуховування музики, з концентрацією на внутрішніх відчуттях, має гіпнотичний ефект, який використовували шамани, для досягнення спеціальних станів свідомості. Од же, саме емпіричний метод, а саме опит змагальної діяльності та аналіз своїх відчуттів дозволяє спортсмен створювати свої, індивідуальні засоби психологічної підготовки до змагань, а саме загоди роботи зі своїм станом свідомості.

Більшість ритуальних дій, які спортсмени використовують перед змаганнями, або в період змагань відносить до технік заземлення в психотерапії. Техніки заземлення прекрасний інструмент для ситуацій, коли ми схвильовані або налякані, їх можна використовувати, де б ми не знаходилися. Як показали результати нашого дослідження, використовуючи техніки заземлення, у виді ритуальних дій, спортсмени стараються контролювати свою свідомість і тіло в «даний момент», організувати в мозку простір, щоб він заспокоївся і відчути себе трохи більш сконцентрованими.

Аналіз відношення спортсменів до відповідальності за результат у змаганнях, показав, що 85,71 \% опитаних респондентів приймають відповідальність за перемогу або поразку на змаганнях на себе. Також опитані спортсмени високо оцінюють відповідальність тренера, або команди в цілому.

Для вивчення ціннісно-смислової сфери особистос- 


\section{СЛОБОЖАНСЬКИЙ НАУКОВО-СПОРТИВНИЙ ВІСНИК:}

\section{Матеріали XIX Міжнародної науково-практичної конференції «Фізична культура, спорт і здоров'я: стан, проблеми та перспективи»}

ті спортсменів застосовувалася методика «Ціннісні орієнтації». Домінуюча спрямованість ціннісних орієнтацій спортсменів фіксувалася як займана ними життєвапозиція, яка визначалася за критеріями рівня залучення в сфреру праці, сімейно-побутову та досудову активність.

Якісний аналіз результатів дослідження дозволив оцінити життєві ідеали та ієрархію життєвих цілей у обстежених спортсменів.

За результатами нашого дослідження, в системітермінальних ціннісних орієнтацій особистості, обстежених спортсменів, цінності особистого життя (любов, духовна і фізична близькість з коханою людиною, здоров'я, наявність хороших і вірних друзів) домінують над цінностями професійної самореалізації (активне діяльне життя, цікава робота, суспільне визнання, продуктивне життя). Конкретні цінності (повнота та емоційна насиченість життя, фрізичне і психічне благополуччя, повага оточуючих, колективу, товаришів і друзів по спорту, максимально повне використання своїх можливостей, сил і здібностей) переважають над абстрактними цінностями (свобода, пізнання, можливість розширення свого кругозору, загальної культури, інтелектуального розвитку).

Якісний аналіз інструментальних цінностей у обстежених спортсменів, дозволив оцінити їх особистісні риси, важливі в якості інструментів для досягнення звичайних цілей, а так само уявлень про норми поведінки. В системі інструментальних цінностей, як особистісна особливість спортсменів, які займаються спортивним туризмом, домінують життєрадісність, почуття гумору, позитивне ставлення до життя в будь-яких ії̈ проявах, довіра до майбутнього життя, глибоке розуміння того блага, яким $€$ сам факт існування людини. Цінності спілкування (чуй- ність, терпимість, альтруїзм, вихованість) переважають над моральними цінностями (відповідальність, почуття обов'язку, вміння тримати своє слово, високі запити, високі вимоги до життя і високі досягнення) і цінностями справи (охайність, порядок у справах, старанність, дисциплінованість, раціоналізм, вміння тверезо і логічно мислити, приймати обдумані рішення). Конформістські цінності (вихованість) поступаються альтруїстичних (терпимість, чуйність).

Таким чином, ціннісні орієнтації особистості спортсменів, які займаються екстремальними видами спорту, а саме спортивним туризмом, виступають в якості основи для формування життєвої стратегії і багато в чому визначають лінію їх професійного розвитку. Основними характеристиками типу особистості, притаманними обстеженим представникам екстремального виду спорту, $є$ орієнтація на етичні цінності, а також прагнення до фрізичного і духовно-морального самовдосконалення.

\section{Висновки /Дискусія}

Для контролю над своїм психологічним станом, спортсмени застосовують різні ритуали та духовні практики, та при цьому повністю беруть на себе відповідальність за результат на змаганнях. Використання індивідуальних ритуалів дозволяє спортсменам контролювати свій стан свідомості.

Використання спортсменам ритуалів та духовних практик, залежить як і від культурних особливостей обстежених спортсменів, від їх особистісних орієнтирів та ціннісних орієнтацій, віросповідання та сили нервової системи.

Конфлікт інтересів. Автори заявляють, що немає конфлікту інтересів, який може сприйматися таким, що може нанести шкоду неупередженості статті.

Джерела фонансування. Ця стаття не отримала фінансової підтримки від державної, громадської або комерційної організації.

\section{Список посилань}

1. Бахчанян, Г. С. (2009), "Мотивація інтересу до занять фізичною культурою та спортом", Педагогіка і психологія, № 4.

2. Гант, О. Є. (2015), "Алгоритм оцінки функціонального стану спортсмена як показника його «психологічного здоров'я»", Вплив досягнень психологічних та педагогічних наук на розвиток сучасного суспільства: матеріали міжнар. наук.-практ. конф., Харків.

3. Гант, Е. Е. (2014), "Влияние профессионального стресса на личность спортсменов", The 1-st international conference on the Eurasian scientific development, Vienna, Austria.

4. Гант, О. Є. (2015), "Характеристики ціннісних орієнтацій особистості в боксі та тайбоксі", Девіантна поведінка: соціологічні, психоллогічні, юридичні аспекти: матеріали міжнар.наук.-практ. конф., Харків.

5. Леонтьев, Д. А. (2011), "Феномен рефлексии в контексте проблемы саморегуляции", Психологические исследования: электрон. науч. журн. № 2 (16). URL: http://psystudy.ru/index.php/num/2011n2-16/463-leontiev-averina16.html (дата звернення: 5.11.2019).

6. Волкова, И. П. (2002), Практикум по спортивной психологии, СПб, Питер, 288 с.

7. Родионов, А. В. (2006), Влияние психологических факторов на спортивный результат, Физкультура и спорт, Москва

8. Рудик, П. А. (1982), "Психологические аспекты спортивной деятельности", Психология и современный спорт, Москва, Физкультура и спорт,

C. $14-40$.

9. Энциклопедия психодиагностики, Психодиагностика взрослых, ред.-сост. Д. Я. Райгородский, Самара, Издательский дом «БахрахM», 2009, 704 c.

Стаття надійшла до редакції: 11.11 .2019 р.

Опубліковано: 30.12.2019 р.

Аннотация. Елена Гант, Ксения Мликова. Использование спортсменами духовных практик и ритуалов при подготовке к соревнованиям. Цель исследования - изучить особенности подготовки ксоревнованиям в украинских и латышский спортсменов. Материал и методы исследования: анализ научно-методической литературы, анкетирование, методика «Ценностные ориентации» Рокича. Результаты проведен теоретический анализ проблемы психологической подготовки к соревнованиям у спортсменов. Опредлено, что помимо классических психологическихтехник спортсмены применяют различные ритуалы и духовке практики. Проанализировано отношение к ответственности за результат в соревнованиях в латышский и украинских спортсменов. Выводы: 85,72\% обследованных спортсменов, используют различные ритуальные действия и духовные практики перед соревнованиями, и при этом полностью берут на себя ответственность за результат на соревнованиях. Использование спортсменам ритуалов и духовных практик, зависит как и от культуральных особенностей обследованных спортсменов, от их личностных ориентиров и ценностных ориентаций, вероисповедания и силы нервной системы.

Ключевые слова: спорт, спортсмены, психологическая подготовка, духовные практики. 
Abstract. Olena Gant, Ksenia Mlikova. The use of spiritual practices and rituals by athletes in preparation for the competition. The purpose of the study is to study the features of preparation for competitions in Ukrainian and Latvian athletes. Material and research methods: analysis of scientific and methodological literature, questionnaires, Rokich's "Value Orientations" methodology. Results A theoretical analysis of the problem of psychological preparation for the competition among athletes. It is determined that in addition to classical psychological techniques, athletes use various rituals and practice ovens. The attitude to responsibility for the result in competitions in Latvian and Ukrainian athletes is analyzed. Conclusions: \% of the examined athletes use various ritual actions and spiritual practices before the competition, and at the same time take full responsibility for the result in the competition. The use of rituals and spiritual practices by athletes depends both on the cultural characteristics of the athletes examined, on their personal orientations and value orientations, religion and the strength of the nervous system.

Keywords: sports, athletes, psychological preparation, spiritual practices.

\section{References}

1.Bakhchanian, H. S. (2009), "Motivating interest in physical education and sports ", Pedahohika i psykholohiia, No. 4. (in Ukr.).

2. Hant, O. Ye. (2015), "An algorithm for assessing an athlete's functional status as an indicator of his / her "psychological health", Vplyv dosiahnen psykholohichnykh ta pedahohichnykh nauk na rozvytok suchasnoho suspilstva: materialy mizhnar. nauk.-prakt. konf., Kharkiv. (in Ukr.).

3.Gant, E. E. (2014), "The influence of professional stress on the personality of athletes", The 1-st international conference on the Eurasian scientific development, Vienna, Austria. (in Russ).

4.Hant, O. Ye. (2015), " Characteristics of personality value orientations in boxing and boxing", Deviantna povedinka: sotsiolohichni, psykholohichni, yurydychni aspekty: materialy mizhnar.nauk.-prakt. konf., Kharkiv. (in Ukr.).

5.Leontev, D. A. (2011), "The phenomenon of reflection in the context of the problem of self-regulation", Psihologicheskie issledovaniya: elektron. nauch. zhurn. No.2 (16). URL: http://psystudy.ru/index.php/num/2011n2-16/463-leontiev-averina16.html (in Russ).

6.Volkova, I. P. (2002), Praktikum po sportivnoy psihologii [Workshop on Sports Psychology], SPb. Piter, $288 \mathrm{c}$. (in Russ).

7.Rodionov, A. V. (2006), Vliyanie psihologicheskih faktorov na sportivnyiy rezultat [The influence of psychological factors on athletic performance], Fizkultura i sport, Moskva (in Russ).

8.Rudik, P. A. (1982), " Psychological aspects of sports", Psihologiya i sovremennyiy sport, Moskva, Fizkultura i sport, pp. 14-40. (in Russ). 9.Entsiklopediya psihodiagnostiki, Psihodiagnostika vzroslyih [Encyclopedia of psychodiagnostics, Psychodiagnostics of adults], red.-sost. D. Ya.Raygorodskiy, Samara, Izdatelskiy dom «Bahrah-M», 2009, 704 p. (in Russ).

Received: 11.11 .2019 .

Published: 30.12 .2019 .

\section{Відомості про авторів / Information about the Authors}

Олена Гант: к. психол. н., доцент; Харківська державна академія фізичної культури: вул. Клочківська 99, Харків, 61058, Україна. Елена Гант: к. психол. н., доцент; Харьковская государственная академия фризической культуры; ул. Клочковская 99, 61058, г. Харьков, Украина.

Olena Gant: PhD (Psychology), Associate Professor; Kharkiv State Academy of Physical Culture: Klochkivska str. 99, Kharkiv, 61058, Ukraine.

ORCID.ORG/0000-0001-7729-4914

E-mail: lenaagant@gmail.com

Ксенія Млікова: психолог, коуч, член правління компанії Buildimpeks, м. Рига, Латвія, leriku 15, LV - 1084.

Ксения Мликова: психолог, коуч, член правления компании Buildimpeks., Г. Рига, Латвия, leriku 15, LV - 1084.

Ksenia Mlikova: Psychologist, Coach, Board Member of Buildimpeks, Riga, Latvia, leriku 15, LV - 1084.

E-mail: ksenijamlikova@gmail.com 